\title{
How phosphorus limitation can control climate-active gas sources and sinks
}

\author{
Nathalie Gypens ${ }^{\mathrm{a}, *}$, Alberto V. Borges ${ }^{\mathrm{b}}$, Caroline Ghyoot ${ }^{\mathrm{a}}$ \\ a Université Libre de Bruxelles, Laboratoire d'Ecologie des Systèmes Aquatiques, CP-221, Bd du Triomphe B-1050, Belgium \\ b Université de Liège, Unité d'Océanographie Chimique, Institut de Physique (B5), B-4000, Belgium
}

\section{A R T I C L E I N F O}

\section{Article history:}

Received 7 September 2016

Received in revised form 1 February 2017

Accepted 8 February 2017

Available online 10 February 2017

\begin{abstract}
A B S T R A C T
Since the 1950's, anthropogenic activities have increased nutrient river loads to European coastal areas. Subsequent implementation of nutrient reduction policies have led to considerably reduction of phosphorus (P) loads from the mid-1980's, while nitrogen (N) loads were maintained, inducing a P limitation of phytoplankton growth in many eutrophied coastal areas such as the Southern Bight of the North Sea (SBNS). When dissolved inorganic phosphorus (DIP) is limiting, most phytoplankton organisms are able to indirectly acquire P from dissolved organic P (DOP). We investigate the impact of DOP use on phytoplankton production and atmospheric fluxes of $\mathrm{CO}_{2}$ and dimethylsulfide (DMS) in the SBNS from 1951 to 2007 using an extended version of the RMIRO-BIOGAS model. This model includes a description of the ability of phytoplankton organisms to use DOP as a source of P. Results show that primary production can increase up to 30\% due to DOP uptake under limiting DIP conditions. Consequently, simulated DMS emissions also increase proportionally while $\mathrm{CO}_{2}$ emissions to the atmosphere decrease, relative to the reference simulation without DOP uptake.
\end{abstract}

(c) 2017 Elsevier B.V. All rights reserved.

\section{Introduction}

Most of the coastal marine ecosystems bordering industrialized countries are strongly affected by changes in anthropogenic nutrient loads. Since the 1950's, dissolved inorganic phosphorus (DIP) and dissolved inorganic nitrogen (DIN) concentrations in inland waters and coastal areas have substantially increased in response to population increase, industrialization, and intensive farming practices. As a result, these coastal marine ecosystems undergo eutrophication (Cloern, 2001). However, due to management policies aiming at reducing eutrophication (implementation of wastewater treatment and banishment of P-based detergents), phosphorus (P) loads decreased after the mid-80's in several coastal ecosystems, while nitrogen $(\mathrm{N})$ loads remained generally high because of continued use of artificial fertilizers in agriculture (Cadée and Hegeman, 2002; Loebl et al., 2009; Philippart et al., 2007). Consequently, phytoplankton growth in these coastal areas is now limited by P availability (e.g. Harrison et al., 1990; Philippart et al., 2007; Rabalais et al., 2002; Trommer et al., 2013; Ly et al., 2014).

Changes in ambient nutrient concentrations modify the magnitude of primary production but can also affect the phytoplankton community composition (e.g., increased occurrence of harmful algal blooms) (Paerl, 1988; Philippart et al., 2000; Heisler et al., 2008), grazing and transfer to higher trophic levels (Malzahn et al., 2007; Finkel et al., 2010), and biogeochemical cycles (Borges and Gypens, 2010). These changes in

\footnotetext{
* Corresponding author.

E-mail address: ngypens@ulb.ac.be (N. Gypens).
}

ecosystem structure impact the emission/absorption by aquatic ecosystems of greenhouse gases ( $\mathrm{GHG}$ ), such as $\mathrm{CO}_{2}$, and other climate-active gases, such as dimethylsulfide (DMS) (Gypens et al., 2009; Gypens and Borges, 2014). Correctly predicting changes in ecosystem structure in response to environmental change is then of prime importance in order to estimate and predict the role of aquatic ecosystems on global biogeochemical cycles and on the emission/absorption of GHG and climate-active gases by marine ecosystems.

Accurately predicting these changes requires that models correctly describe the link between phytoplankton growth and uptake of nutrients. Although high nutrient loads generally result in high algal biomass, phytoplankton nutrient requirements are specific (Quigg et al., 2003; Lagus et al., 2004), depending on acclimation to light intensity (Klausmeier et al., 2008; Sunda and Huntsman, 1997) or on the ability to store nutrients (as polyphosphate, nitrogen and ferritin reserves) (Geider and La Roche, 2002; Klausmeier et al., 2008). Moreover, most phytoplankton organisms are also able to acquire nutrients from organic sources when inorganic forms (their preferred source) are limiting. To acquire nutrients from organic sources, phytoplankton organisms can directly ingest prey or particulate organic matter by phagotrophy (mixotrophy) or absorb dissolved organic matter by osmotrophy. When DIP is limiting, most phytoplankton organisms are also able to indirectly acquire P from dissolved organic P (DOP; e.g., sugar phosphates, phospholipids, nucleotide phosphates) by synthesizing ecto-enzymes that hydrolyze DOP to release DIP (Kuenzler and Perras, 1965; Cembella et al., 1984; Flynn et al., 1986; Hoppe, 2003; Glibert and Legrand, 2006; Liu et al., 2012). Alkaline phosphatase (AP) is one of 
Table 1

Parameter values.

\begin{tabular}{|c|c|c|c|c|}
\hline Parameter & Value & Units & Explanation & Source \\
\hline$C P_{F}$ & 65 & $\mathrm{~mol} \mathrm{C} \mathrm{mol} \mathrm{P}^{-1}$ & $\mathrm{C}: \mathrm{P}$ ratio for $\mathrm{F}$ metabolites & Lancelot et al. (2005) \\
\hline$k_{P}^{D A}$ & 0.3 & $\mathrm{mmol} \mathrm{P} \mathrm{m}^{-3}$ & Half-saturation constant for DIP uptake by diatoms & Ghyoot et al. (2017) \\
\hline$k_{P}^{N F}$ & 0.25 & $\mathrm{mmol} \mathrm{P} \mathrm{m}^{-3}$ & Half-saturation constant for DIP uptake by nanoflagellates & Ghyoot et al. (2015) \\
\hline$k_{P}^{O P}$ & 0.3 & $\mathrm{mmol} \mathrm{P} \mathrm{m}^{-3}$ & Half-saturation constant for DIP uptake by Phaeocystis colonies & Ghyoot et al. (2015) \\
\hline$k_{\text {uptP }}^{\text {reg }}$ & 0.01 & - & Half-saturation constant for upt $t_{P}$ regulation by $S_{P}$ & Ghyoot et al. (2015) \\
\hline upt $t_{P}^{\max D A}$ & 0.31 & $\mathrm{~h}^{-1}$ & Max P uptake rate by diatoms & Ghyoot et al. (2017) \\
\hline upt $t_{P}^{\operatorname{maxNF}}$ & 0.22 & $\mathrm{~h}^{-1}$ & Max P uptake rate by nanoflagellates & Ghyoot et al. (2015) \\
\hline upt $t_{P}^{\operatorname{maxOP}}$ & 0.44 & $\mathrm{~h}^{-1}$ & Max P uptake rate by Phaeocystis colonies & Ghyoot et al. (2015) \\
\hline$X_{S_{p}} \operatorname{maxDA}$ & 0.15 & - & Maximum $\mathrm{S}_{\mathrm{P}} /\left(\mathrm{F} / \mathrm{CP}_{\mathrm{F}}\right)$ ratio for diatoms & Ghyoot et al. (2017) \\
\hline$X_{S_{p}}^{\operatorname{maxNF}}$ & 0.2 & - & Maximum $\mathrm{S}_{\mathrm{P}} /\left(\mathrm{F} / \mathrm{CP}_{\mathrm{F}}\right)$ ratio for nanoflagellates & Ghyoot et al. (2017) \\
\hline$X_{S_{P}} \operatorname{maxOP}$ & 0.2 & - & Maximum $\mathrm{S}_{\mathrm{P}} /\left(\mathrm{F} / \mathrm{CP}_{\mathrm{F}}\right)$ ratio for Phaeocystis colonies & Ghyoot et al. (2017) \\
\hline
\end{tabular}

the well-known enzymes responsible for the hydrolysis of DOP. The ability to acquire $P$ from different sources can be particularly important in oligotrophic ecosystems (Arenovski et al., 1995; Mather et al., 2008), but also in eutrophic waters (Rousseau et al., 2004; Burkholder et al., 2008) frequently subjected to nutrient imbalance and where bloomforming harmful algal species, known to be particularly competitive under unbalanced nutrient conditions, can occur (Glibert and Legrand, 2006).

Taking into account the capacity of phytoplankton to grow on organic nutrient sources can modify the intensity of primary production and, therefore, has to be included in model development and prediction. Here, we investigate the impact of the use of organic P on phytoplankton production and its consequences for biogeochemical cycles, in particular, $\mathrm{CO}_{2}$ and DMS exchanges with the atmosphere in the Southern Bight of the North Sea (SBNS). Since the late 1980's, the area is P limited and constitutes therefore an ideal case study (Billen et al., 2001, 2005; Soetaert et al., 2006). The SNBS is characterized by a high primary production resulting from a succession of diatom and Phaeocystis blooms (Lancelot et al., 2007). This latter species has not been reported to be mixotrophic but, in contrast, it has been shown to induce AP synthesis to use DOP as P source when DIP is low (Veldhuis et al., 1987; van Boekel and Veldhuis, 1990). It can be hypothesized that utilization of DOP allows to sustain massive spring blooms of Phaeocystis in the nitrate-enriched waters of the SBNS. Phaeocystis, as other haptophytes in general, is an important producer of dimethylsulfoniopropionate (DMSP) (Keller et al., 1989), the precursor of DMS. The impact of organic $\mathrm{P}$ use on (i) ecosystem primary production and (ii) $\mathrm{CO}_{2}$ and DMS fluxes is studied using an extended version of the R-MIRO-BIOGAS model (previously validated in the SBNS; Gypens et al., 2004, 2014) that includes a description of the ability of phytoplankton organisms to use DOP as a source of P (Ghyoot et al., 2015).

\section{Material and methods}

The MIRO-BIOGAS model describes the dynamics of phytoplankton (diatoms, nanoflagellates and Phaeocystis), zooplankton (microzooplankton and copepods) and bacteria involved in the degradation of organic matter and the regeneration of inorganic nutrients in the water column and the sediment (Lancelot et al., 2005). The model also includes the description of the carbonate system (Gypens et al., 2004) and the DMS(P) cycle (Gypens et al., 2014). The description of the carbonate system is based on the evolution of dissolved inorganic carbon (DIC) and total alkalinity (TA). It allows the calculation of partial pressure of $\mathrm{CO}_{2}\left(\mathrm{pCO}_{2}\right), \mathrm{pH}$ and airsea $\mathrm{CO}_{2}$ fluxes (Gypens et al., 2004). The DMS(P) cycle describes the DMSP and DMS dynamics; those consist of biological transformations by phytoplankton and bacteria as well as physico-chemical processes (i.e., photodegradation and DMS air-sea exchange) (Gypens et al., 2014).

The ability of phytoplankton organisms to use the DOP as a source of $P$ when DIP is limiting was added to the MIRO model according to the simplified formulation suggested in Ghyoot et al. (2015). The biomass of autotrophic organisms is divided into three pools: $\mathrm{F}$ (functional and structural metabolites (e.g., deoxyribonucleic acid, ribonucleic acid proteins) containing $\mathrm{C}, \mathrm{N}, \mathrm{P}$ and $\mathrm{Si}$ for diatoms), $\mathrm{S}_{\mathrm{C}}$ (monomeric carbon provided by photosynthesis or catabolism of $C$ reserves), and $R_{C}$ (carbon reserves). A fourth pool, analogous to $S_{C}$, describes the internal soluble DIP used for F synthesis $\left(S_{P}\right)$. This description decouples photosynthesis from growth. On this basis, the phytoplankton growth is controlled by the availability of carbon, light, and inorganic nutrients. The nutrient limitation follows the minimum law in which $\mathrm{P}$ limitation depends on $\mathrm{X}_{\mathrm{Sp}}$ (the ratio between $\mathrm{S}_{\mathrm{P}}$ and the $\mathrm{P}$ contained in $\mathrm{F}$ (computed based on the $C$ : $P$ ratio of $F, C P_{F}$ ), i.e., $X_{S p}=S_{P} /\left(F / C P_{F}\right)$ ) and $N$ limitation depends on external DIN. In this simplified formulation, AP activity (APA) releasing DIP from DOP is implicitly considered by allowing the direct uptake of DOP when DIP becomes limiting. The total $P$ (DIP + DOP) uptake ( upt $_{\mathrm{P}}$; mmol P m $\mathrm{m}^{-3} \mathrm{~h}^{-1}$ ) is a function of the external DIP + DOP concentrations and the internal $S_{P}$ status expressed by the ratio $\mathrm{X}_{\mathrm{Sp}} / \mathrm{X}_{\mathrm{Sp}}^{\max }(\mathrm{Eq}$. (1)):

$$
u_{P} t_{P}=\operatorname{upt}_{P}^{\max } \cdot \frac{(D I P+D O P)}{(D I P+D O P)+k_{P}} \cdot \frac{\left(1-X_{S p} / X_{S p}^{\max }\right)^{4}}{\left(1-X_{S p} / X_{S p}^{\max }\right)^{4}+k_{u p t P}^{\text {reg }}} \cdot \frac{F}{C P_{F}}
$$

where $\mathrm{upt}^{\mathrm{max}}{ }_{\mathrm{P}}=$ Maximal transport rate of $\mathrm{P}$ at optimal temperature $\left(\mathrm{h}^{-1}\right)$

$\mathrm{k}_{\mathrm{P}}=$ Half-saturation constant of $\mathrm{P}$ uptake $\left(\mathrm{mmol} \mathrm{P} \mathrm{m}^{-3}\right)$

$\mathrm{X}_{\mathrm{Sp}}=$ Ratio between $\mathrm{S}_{\mathrm{P}}$ and $\mathrm{P}$ included in $\mathrm{F}$, i.e., $\mathrm{S}_{\mathrm{P}} /\left(\mathrm{F} / \mathrm{CP}_{\mathrm{F}}\right)$ ( $\mathrm{mmol} \mathrm{P} \mathrm{mmol} \mathrm{P}{ }^{-1}$ )

$\mathrm{X}_{\mathrm{Sp}}^{\max }=$ Maximal ratio between $\mathrm{S}_{\mathrm{P}}$ and $\mathrm{P}$ included in $\mathrm{F}$ ( $\mathrm{mmol} \mathrm{P} \mathrm{mmol} \mathrm{P} \mathrm{P}^{-1}$ )

$\mathrm{k}^{\text {reg }}{ }_{\text {uptP }}=$ Half-saturation constant of upt $_{\mathrm{P}}$ regulation by $\mathrm{S}_{\mathrm{P}}$ ( $\mathrm{mmol} \mathrm{P} \mathrm{mmolP}{ }^{-1}$ )

$\mathrm{CP}_{\mathrm{F}}=$ Carbon to phosphorus ratio of $\mathrm{F}\left(\mathrm{mmol} \mathrm{C} \mathrm{mmol} \mathrm{P}^{-1}\right)$

Parameter values and references are given in Table 1.

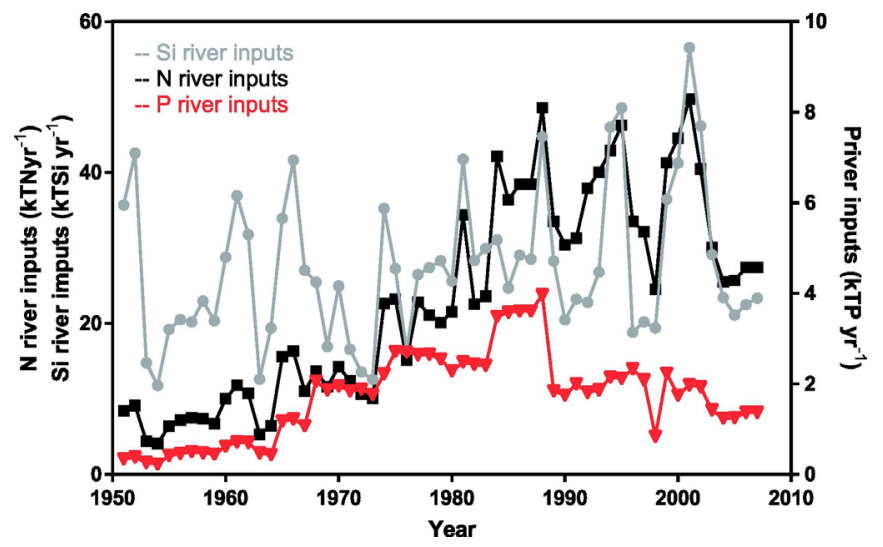

Fig. 1. Evolution of annual river loads of silica $(\mathrm{Si})$, nitrogen $(\mathrm{N})$ and phosphorus $(\mathrm{P})$ in the Belgian coastal zone from 1951 to 2007 simulated by R-MIRO-BIOGAS. 
The proportions of DIP and DOP that are taken up are functions of (i) their respective concentrations and (ii) a preference function for DIP over DOP ( $f_{\text {DIP }}$; Eq. (2)) based on the external DIP. DOP uptake decreases to zero when the external DIP is high. On the opposite, when DIP is low, most of the $\mathrm{P}$ input is provided by DOP.

$f_{D I P}=1-\frac{D I P}{D I P+k_{f D I P}}$

The half-saturation constant for DOP uptake inhibition by DIP ( $\mathrm{k}_{\mathrm{fDIP}}$; Eq. (2)) has been estimated at $0.2 \mathrm{mmol} \mathrm{P} \mathrm{m}^{-3}$ (Ghyoot et al., 2015). This simplified formulation was derived from a mechanistic model explicitly describing the ability of phytoplankton to use DOP when DIP is limiting, by synthesizing AP that releases DIP from DOP and describing the main processes related to the $\mathrm{P}$ metabolism, including DIP transport, intracellular accumulation and assimilation (Ghyoot et al., 2015).

To take account for the ability of bacteria to also use DOP (by the use of AP) as P source when DIP is limiting (e.g. Hoppe, 2003; Labry et al., 2005; Ivancic et al., 2010), the description of bacterial growth and associated nutrient uptake were modified from the original description of Lancelot et al. (2005). A P limitation of bacterial growth was added as a Michaelis-Menten function. The half-saturation constant for $\mathrm{P}$ limitation was estimated at $0.01 \mathrm{mmol} \mathrm{P} \mathrm{m}^{-3}$ (Codeço and Grover,
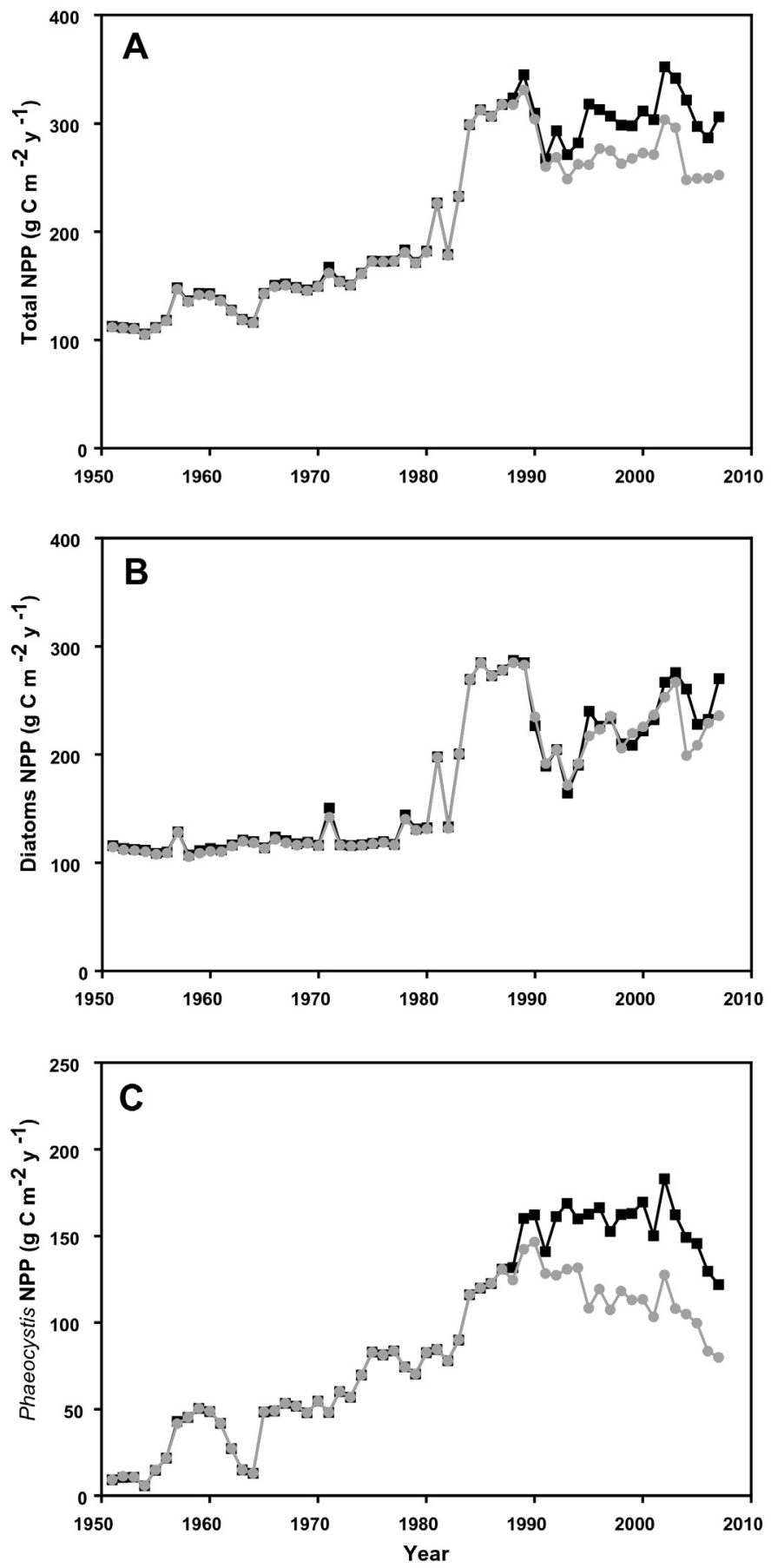

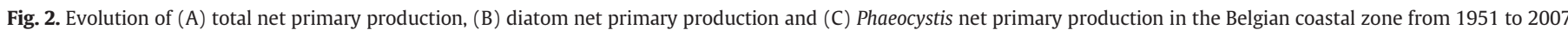
simulated by R-MIRO-BIOGAS with (black line) and without (grey line) taking into account the ability to use DOP as a P source for phytoplankton growth. 
2001). The relative proportions of DIP and DOP taken up to sustain bacterial growth are estimated similarly to phytoplankton ( $\mathrm{f}_{\mathrm{DIP}}$; Eq. (2)). The half-saturation constant for DOP uptake inhibition by DIP ( $\mathrm{k}_{\mathrm{fDIP}}$; Eq. (2)) has been estimated at $0.01 \mathrm{mmol} \mathrm{P} \mathrm{m}^{-3}$ to take account the higher affinity of bacteria for DIP.

To estimate the impact of nutrient loads modification on the coastal zone, the marine biogeochemical model was coupled to the RIVERSTRAHLER model. The RIVERSTRAHLER model (Garnier et al., 2002) describes carbon and nutrient transformations along the river system as a function of meteorological conditions and a GIS (geographic information system) description of human activity on the watershed (Billen et al., 2001, 2005; Passy et al., 2013). The coastal model is implemented in a multi-box 0D frame (Lancelot et al., 2005) from the Western Channel to the Belgian Coastal Zone (BCZ) using the 10-days RIVERSTRAHLER input as river forcing, forced by daily wind speed, sea surface temperature (SST), monthly atmospheric $\mathrm{pCO}_{2}$, daily global solar radiation (climatology for 1989-1999) and river DIC and TA inputs (Seine and Scheldt rivers) computed as a function of freshwater discharge (Gypens et al., 2009). Two simulations were performed for the 1950-2007 period after a 10 year spin-up and analysis of output results focusses on the $\mathrm{BCZ}$. In the reference simulation we consider that DIP is the only P source available for phytoplankton, while bacteria can use both DIP and DOP. In the second simulation, we consider DIP and DOP as P source for both bacteria and phytoplankton.

\section{Results}

\subsection{Diatom and Phaeocystis production}

$\mathrm{N}$ and $\mathrm{P}$ annual river loads increased from 1950 to the mid 1980's (Fig. 1). Afterwards, P loads decreased and N loads remained high, leading to a change in $\mathrm{N}$ :P ratio and $\mathrm{P}$ limitation of primary production. In response to the changes in nutrient river loads, total net primary production (NPP) increased in the BCZ (Fig. 2A). From 1951 to 2007, total NPP increased from 111 to $252 \mathrm{~g} \mathrm{C} \mathrm{m}^{-2} \mathrm{y}^{-1}$. NPP change was accompanied by a change in the relative importance of phytoplanktonic communities (with diatoms to Phaeocystis ratio decreasing from 10 to 1.5 during the simulated period; Fig. 2B, C). Each year, the seasonal succession was characterized by a succession of spring diatoms, Phaeocystis and summer diatoms (Lancelot et al., 2005). After the decline of the Phaeocystis bloom, the area was characterized by intense bacterial activity. The relative importance of these blooms varied from year to year (Gypens et al., 2007, 2009; Lancelot et al., 2007). From 1950 to 1970, annual production of diatoms was largely higher than that of Phaeocystis with average values, respectively, around 115 and $33 \mathrm{~g} \mathrm{C} \mathrm{m}^{-2} \mathrm{y}^{-1}$. Phaeocystis production represented on averaged 20\% on annual NPP production. From 1970 onwards, the combination of increased nutrient loads and of the increase of the N:P ratio, favored Phaeocystis production, bringing it to a level similar to that of diatoms (Fig. 2B, C). This was particularly exacerbated in the 1990's when the sustained $\mathrm{N}$ loads
Without DOP
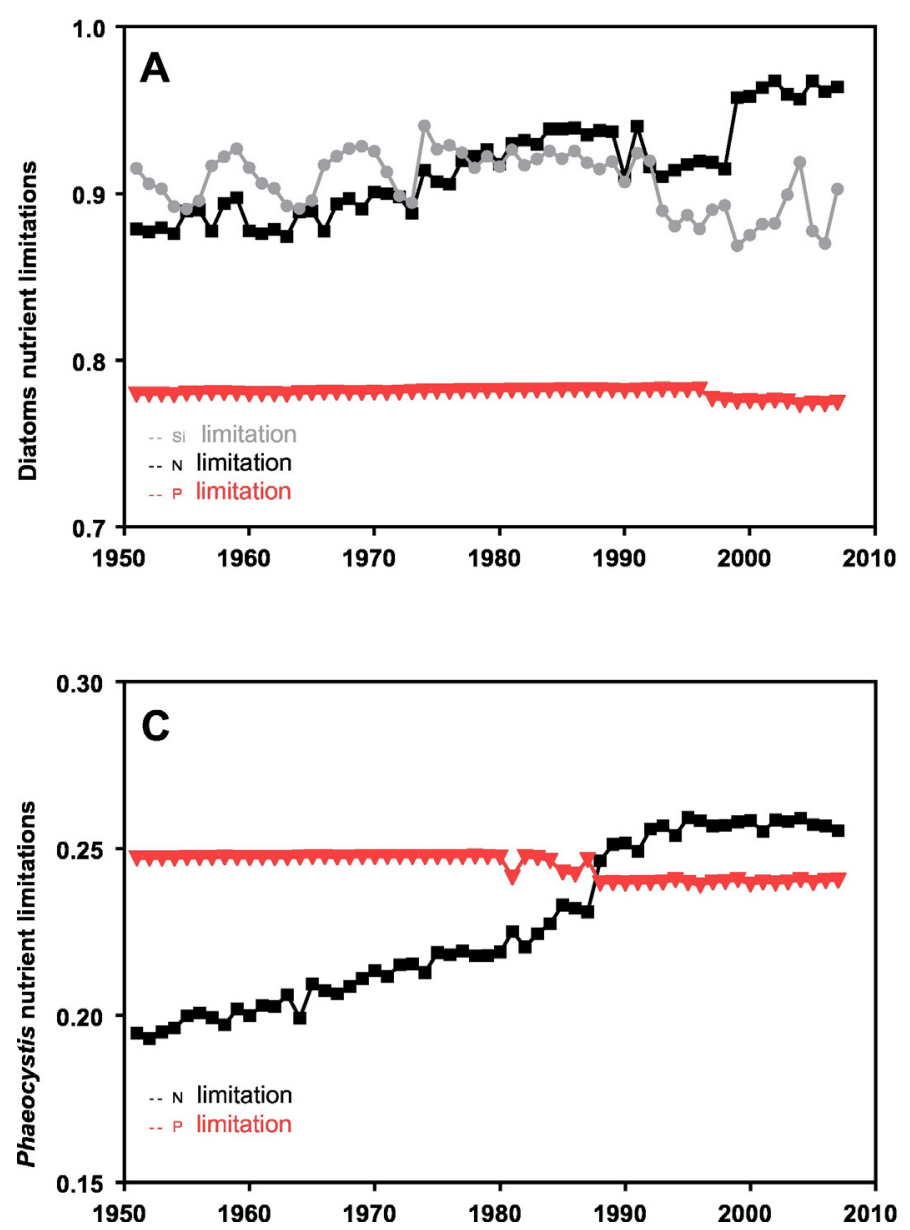

With DOP

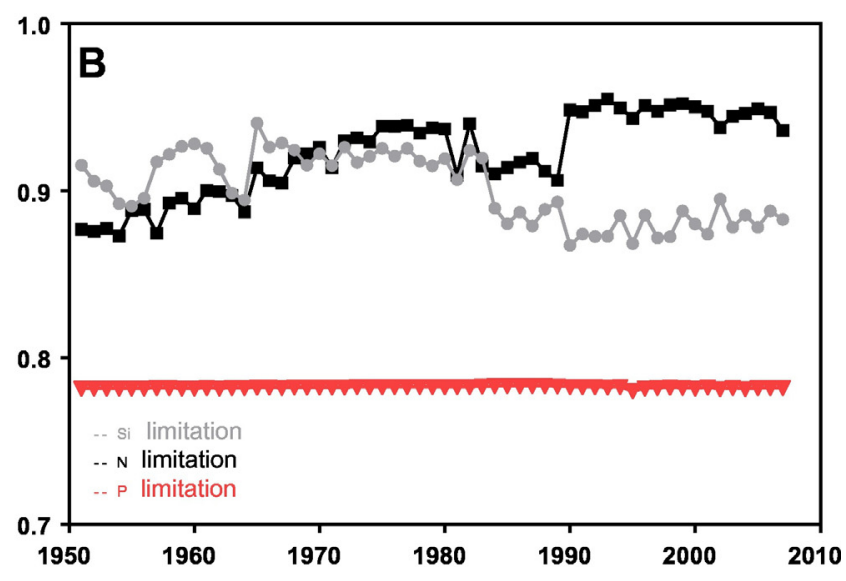

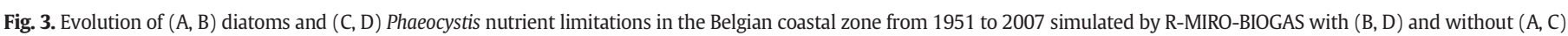
taking into account the ability to use DOP as a P source for phytoplankton growth. 
started to combine with decreasing P river loads (Fig. 2B, C). In 1993, Phaeocystis production account for $45 \%$ of the total NPP.

The ability of phytoplankton to use DOP as additional source of $\mathrm{P}$ when DIP is limiting modified the magnitude of phytoplankton production. For diatoms, the increase in $\mathrm{P}$ availability was not sufficient to strongly modify the annual biomass that only slightly increased at the end of the simulated period (Fig. 2B). From 1988 onwards, Phaeocystis production increased up to $50 \%$ due to DOP use (Fig. 2C). DOP use mainly impacted model results at the end of the simulated period when $\mathrm{P}$ river loads decreased (Fig. 1), inducing a P limitation of phytoplankton growth (Fig. 3A, C). From 1951 to the end of the 80's, N is the limiting nutrient of Phaeocystis growth (Fig. 3C). During this period, P limitation is quite constant but NPP increase (Fig. 2C). At the end of the 80's, Phaeocystis growth limitation shifted from a $\mathrm{N}$ limitation to a P limitation (Fig. 3C) as a result of P river loads decreased (Fig. 1). Considering both DOP and DIP as P sources resulted in decreased P limitation (Fig.
3D) and favored Phaeocystis production from 1980 onwards (Fig. 2C). The increase in biomass will modify all the nutrient limitations and therefore that of $\mathrm{N}$ also that will be much more important and could become the nutrient limiting Phaeocystis growth (Fig. 3D). For diatoms, the increase in P availability is not sufficient to strongly modify the annual biomass (Fig. 2B) and the limitations do not change very much. However, the use of DOP alleviated the P limitation of diatom growth (Fig. 3B), particularly in summer (not shown) when biomass can increase as a result of DOP used.

\subsection{Climate-active gas fluxes}

The exchange with the atmosphere of $\mathrm{CO}_{2}$ and particularly of DMS responded to the modification of the primary production from 1951 to 2007. The increase (decrease) of river nutrient loads increased (decreased) primary production, atmospheric $\mathrm{CO}_{2} \operatorname{sink}$ (Fig. $4 \mathrm{~A}$ ) and DMS
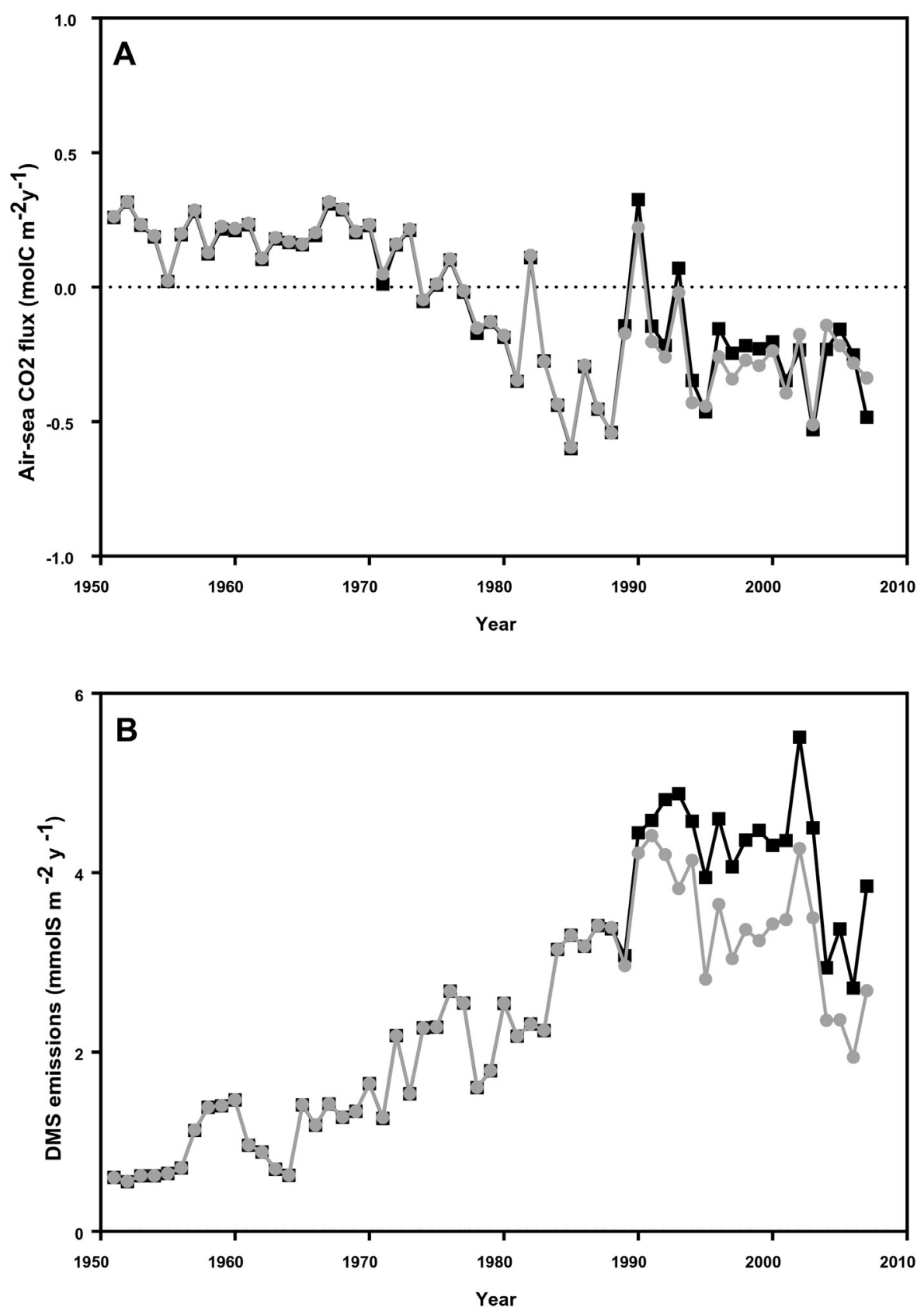

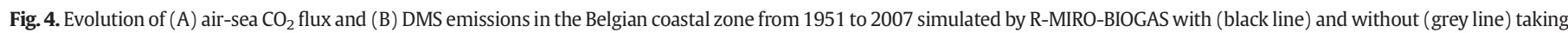
into account the ability to use DOP as a P source for phytoplankton growth. 


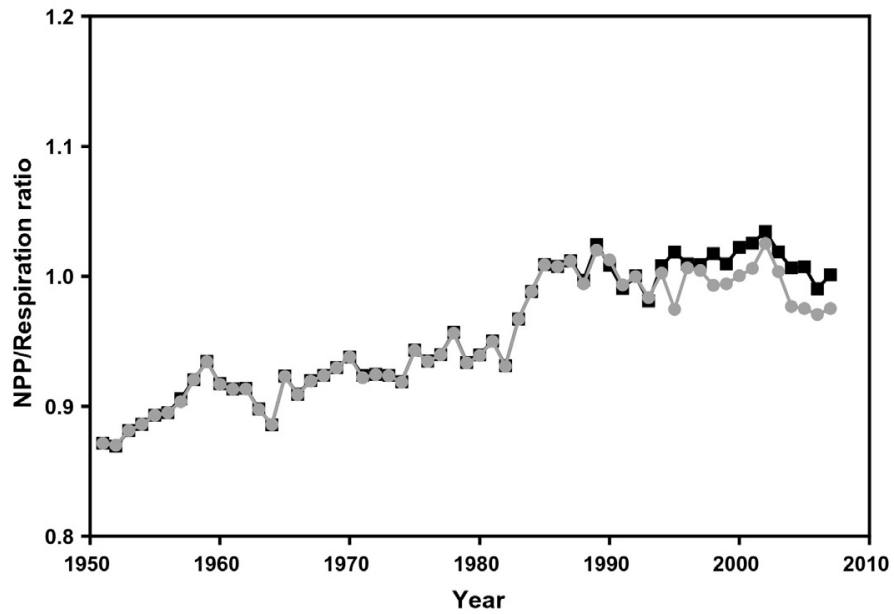

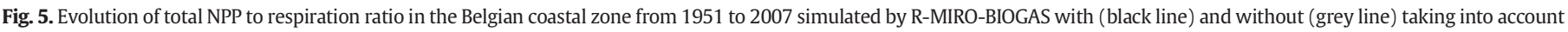
the ability to use DOP as a P source for phytoplankton growth.

emissions (Fig. 4B). From 1951 to 2007, the atmospheric $\mathrm{CO}_{2}$ flux varied from a source of $\mathrm{CO}_{2}$ of $0.7 \mathrm{~mol} \mathrm{C} \mathrm{m}{ }^{-2} \mathrm{y}^{-1}$ to a sink of $\mathrm{CO}_{2}$ of about $0.9 \mathrm{~mol} \mathrm{C} \mathrm{m}^{-2} \mathrm{y}^{-1}$. During the same period, DMS emissions increased from 1.6 to $7.3 \mathrm{mmol} \mathrm{S} \mathrm{m}^{-2} \mathrm{y}^{-1}$. The model representation taking into account the capacity of phytoplankton to use DOP modified climate-active gas exchanges with the atmosphere. Simulated DMS emissions (Fig. 4B) increased every year since 1988 when considering the use of DOP by phytoplankton. In parallel, $\mathrm{CO}_{2}$ fluxes were also modified but less than DMS fluxes and the direction of the change varied from one year to another (Fig. $4 \mathrm{~A}$ ). But in general the sink of $\mathrm{CO}_{2}$ atmospheric increased at the end of the simulated period (Fig. 4A) in response to use of DOP and increase of primary production. Changes in primary production impacted DMS and $\mathrm{CO}_{2}$ fluxes differently. The DMS emissions mainly resulted from, and were proportional to, the modification of Phaeocystis production. The $\mathrm{CO}_{2}$ fluxes resulted from the balance of autotrophic and heterotrophic processes. Autotrophic processes were favored compared to heterotrophic processes when phytoplankton growth on organic P was included in the model (Fig. 5).

\section{Discussion}

The concentration of dissolved nutrients or their ratios are not always reliable to predict primary production or phytoplankton nutrient

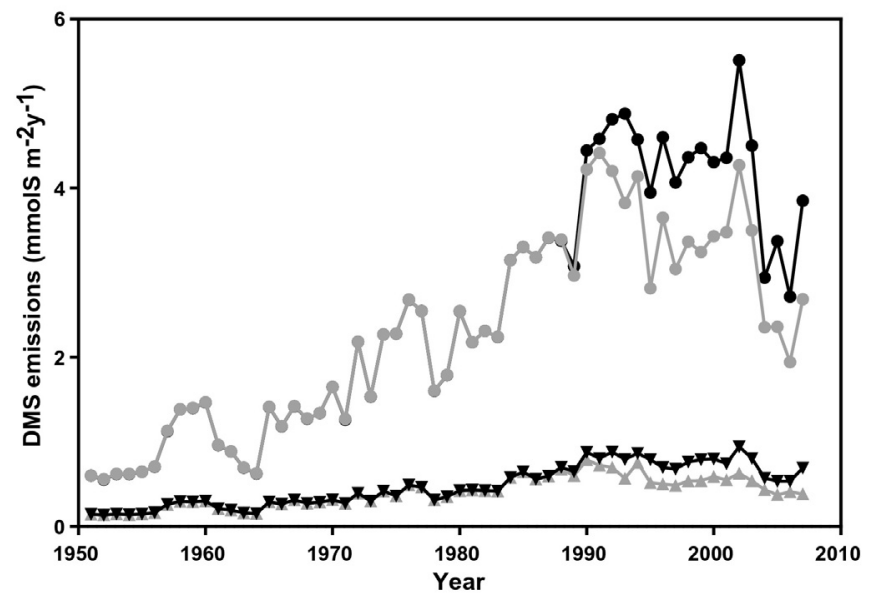

Fig. 6. Evolution of DMS emissions in the Belgian coastal zone from 1951 to 2007 simulated by R-MIRO-BIOGAS with (black line) and without (grey line) taking into account the ability to use DOP as a P source for phytoplankton growth considering that the whole (circle) or just a part (triangle) of bacterial community is able to degrade DMSP. limitation (e.g. Trommer et al., 2013; Letscher and Moore, 2015). Taking account the use of organic $P$ by phytoplankton and by bacteria can change heterotrophic/autotrophic process balance and influence carbon cycling, particularly in P limited environments (Løvdal et al., 2007). Among the processes influencing nutrient availability or use, APA can be important in eutrophied coastal areas (Veldhuis et al., 1987) and can impact the ecosystem structure and its functioning. Our results confirm that the use of organic compounds as nutrient source need to be taken into account in the representation of primary production in mathematical models to avoid underestimation of primary production if only dependent on the availability of inorganic nutrients (Llebot et al., 2010).

Both interspecific competition and competition among trophic compartments are important to estimate the importance of GHG and other climate-active gas emissions. Regarding the $\mathrm{S}$ cycle and DMS emissions, DMS $(\mathrm{P})$ production and emission are species specific. Therefore, phytoplankton dominance and competition between phototroph organisms will determine the importance of the atmospheric flux together with the importance of viral lysis of phytoplankton cells, the activity of grazers, and the activity and composition of the heterotrophic community. In particular, bacterial DMS production depends on their biomass, composition and relative demands of carbon versus sulfur. As a first approximation, we considered in the model that the whole bacterial community was able to consume and degrade DMSP in DMS or other degradation products as $\mathrm{SO}_{4}^{2-}$ or methanethiol (MeSH) (Gypens et al., 2014). However, this is not correct and previous sensitivity tests showed the importance of this simplification on the magnitude of DMS emissions (Gypens et al., 2014). In absence of sufficient information on seasonal changes in bacterioplankton composition in the studied area and their respective role for DMSP consumption/degradation, it is currently not possible to develop an explicit description of different bacterial groups. However, to test the effect of this hypothesis in our results, an additional simulation was done by modulating bacterial DMS yields based on the variation of bacterial P limitation. Indeed, it has been shown that the availability of nutrients can modulate the composition of heterotrophic bacterial communities (e.g. Thingstad et al., 1998; Pinhassi et al., 2006). In particular, P scarcity was particularly limiting to some Roseobacter clades (Pinhassi et al., 2006), which are abundant in the North Sea area (Zubkov et al., 2001, 2002) and important DMS producers (Gonzalez et al., 1999; Moran et al., 2012). Results showed that if the proportion of bacteria able to transform DMSP into DMS decreased, the magnitude of DMS emissions decreased as well, and the maximal DMS emission simulated in 2002 decreased from 5.5 to $0.95 \mathrm{mmol} \mathrm{S} \mathrm{m}^{-2} \mathrm{y}^{-1}$ (Fig. 6). However, whatever the proportion of bacteria able to use and degrade DMSP, considering the ability by phytoplankton to use DOP increased its biomass and related DMSP 
production and DMS emissions (Fig. 6). For example, in 2002, DMS emissions increased from 4.3 to $5.5 \mathrm{mmol} \mathrm{S} \mathrm{m}^{-2} \mathrm{y}^{-1}$ and 0.63 to $0.95 \mathrm{mmol} \mathrm{S} \mathrm{m}^{-2} \mathrm{y}^{-1}$ (Fig. 6) when considering respectively a part of or all bacteria population able to use/degrade DMSP. Regarding the carbon cycle and $\mathrm{CO}_{2}$ fluxes, $\mathrm{CO}_{2}$ fluxes were related to both autotrophic and heterotrophic processes but (relatively) independent of the bacterio- and phyto-plankton composition. Competition between phototrophic and heterotrophic organisms will therefore determine the importance of the $\mathrm{CO}_{2}$ atmospheric flux, more than phytoplankton community composition.

In the study area, eutrophication modified primary production and induced a shift from $\mathrm{CO}_{2}$ source to the atmosphere to $\mathrm{CO}_{2}$ sink (Gypens et al., 2009; Fig. 4A) and a very strong increase in the DMS emissions to the atmosphere (Gypens et al., 2014; Fig. 4B). Although the SBNS has a relatively small surface area, should such trends be general to eutrophied coastal environments globally, this might have a favorable impact on global warming because $\mathrm{CO}_{2}$ is the main anthropogenic GHG contributing to the increase of radiative forcing, and DMS could induce cooling of the atmosphere (Charlson et al., 1987). Consequently, it is necessary to correctly model the fluxes of these two gases in coastal environments as well as their response to anthropogenic pressures (specifically eutrophication), in addition to other changes that also affect the open ocean such as acidification and warming of surface waters. For the 2000-2007 period, the mean annual $\mathrm{CO}_{2}$ sink was 0.28 and $0.30 \mathrm{~mol} \mathrm{C} \mathrm{m}^{-2} \mathrm{yr}^{-1}$ for the reference simulation and simulation with assimilation of DOP, respectively. For the same period, the mean annual source of DMS was 3.0 and $3.9 \mathrm{mmol} \mathrm{S} \mathrm{m}^{-2} \mathrm{yr}^{-1}$ for the reference simulation and simulation with assimilation of DOP, respectively. Thus, the inclusion of DOP assimilation by phytoplankton induces a moderate change of $\mathrm{CO}_{2}$ sink but an important increase of DMS emission (about 40\%). This is particularly relevant for the correct quantification of the marine emissions of DMS of continental shelves affected by eutrophication. Although continental shelves only occupy $7 \%$ of the total surface of the ocean, continental shelves are also significant sources of DMS emissions (per surface area) with annual average DMS concentration on the European continental shelf ("NE Atlantic Shelves" province) being $50 \%$ higher than in the Atlantic Ocean at the same latitude (“N. Atlantic Drif” province) (Lana et al., 2011).

\section{Acknowledgment}

Caroline Ghyoot was supported by a PhD scholarship funded through the Fonds De La Recherche Scientifique - FNRS (FC-95506) (F.R.S. - FNRS, Belgium). Alberto V. Borges is a senior research associate at the FNRS. We thank an anonymous reviewer and the editor for their constructive comments on the previous version of the manuscript.

\section{References}

Arenovski, A.L., Lim, E.L., Caron, D.A., 1995. Mixotrophic nanoplankton in oligotrophic surface waters of the Sargasso Sea may employ phagotrophy to obtain major nutrients. J. Plankton Res. 17, 801-820.

Billen, G., Garnier, J., Ficht, A., Cun, C., 2001. Modeling the response of water quality in the Seine river estuary to human activity in its watershed over the last 50 years. Estuaries 24, 977-993.

Billen, G., Garnier, J., Rousseau, V., 2005. Nutrient fluxes and water quality in the drainage network of the Scheldt basin over the last 50 years. Hydrobiologia 540:47-67. http:// dx.doi.org/10.1007/s10750-004-7103-1.

Borges, A.V., Gypens, N., 2010. Carbonate chemistry in the coastal zone responds more strongly to eutrophication than to ocean acidification. Limnol. Oceanogr. 55: 346-353. http://dx.doi.org/10.4319/lo.2010.55.1.0346.

Burkholder, J.M., Glibert, P.M., Skelton, H.M., 2008. Mixotrophy, a major mode of nutrition for harmful algal species in eutrophic waters. Harmful Algae 8, 77-93.

Cembella, A.D., Antia, N.J., Harrison, P.J., 1984. The utilization of inorganic and organic phosphorous compounds as nutrients by eukaryotic microalgae: a multidisciplinary perspective: part 1. Crit. Rev. Microbiol. 10, 317-391.

Cloern, J.E., 2001. Our evolving conceptual model of the coastal eutrophication problem Mar. Ecol. Prog. Ser. 210:223-253. http://dx.doi.org/10.3354/meps210223.
Cadée, G.C., Hegeman, J., 2002. Phytoplankton in the Marsdiep at the end of the 20th century; 30 years monitoring biomass, primary production, and Phaeocystis blooms. J. Sea Res. 48, 97-110.

Charlson, R.J., Lovelock, J.E., Andreae, M.O., Warren, S.G., 1987. Oceanic phytoplankton, atmospheric sulphur, cloud albedo and climate. Nature 326:655-661. http://dx.doi.org/ $10.1038 / 326655 \mathrm{a0}$

Codeço, C.T., Grover, J.P., 2001. Competition along a spatial gradient of resource supply: a microbial experimental model. Am. Nat. 157 (3), 300-315.

Flynn, K.J., Öpik, H., Syrett, P.J., 1986. Localization of the alkaline phosphatase and 50nucleotidase activities of the diatom Phaeodactylum tricornutum. J. Gen. Microbiol. 132, 289-298.

Finkel, Z.V., Beardall, J., Flynn, K.J., Quigg, A., Rees, T.A.V., Raven, J.A., 2010. Phytoplankton in a changing world: cell size and elemental stoichiometry. J. Plankton Res. 32, 119-137.

Garnier, J., Billen, G., Hannon, E., Fonbonne, S., Videnina, Y., Soulie, M., 2002. Modeling transfer and retention of nutrients in the drainage network of the Danube River. Estuar. Coast. Shelf Sci. 54:285-308. http://dx.doi.org/10.1006/ecss.2000.0648.

Geider, R.J., La Roche, J., 2002. Redfield revisited: variability of C:N:P in marine microalgae and its biochemical basis. Eur. J. Phycol. 37, 1-17.

Ghyoot, C., Gypens, N., Flynn, K.J., Lancelot, C., 2015. Modelling alkaline phosphatase activity in microalgae under orthophosphate limitation: the case of Phaeocystis globosa J. Plankton Res. 37 (869), 85

Ghyoot, C., Lancelot, C., Flynn, K.J., Mitra, A., Gypens, N., 2017. Introducing mixotrophy into a biogeochemical model describing an eutrophied coastal ecosystem: The Southern North Sea. Prog. Oceanogr.

Glibert, P.M., Legrand, C., 2006. The diverse nutrient strategies of harmful algae: focus on osmotrophy. In: Grane'li, E., Turner, J.T. (Eds.), Ecology of Harmful Algae. Ecol. Stud. 189. Springer, Berlin, pp. 163-175.

Gonzalez, J.M., Kiene, R.P., Moran, M.A., 1999. Transformation of sulfur compounds by an abundant lineage of marine bacteria in the a-subclass of the class Proteobacteria. Appl. Environ. Microbiol. 65 (9), 3810-3819.

Gypens, N., Borges, A.V., 2014. Increase in dimethylsulfide (DMS) emissions due to eutrophication of coastal waters offsets their reduction due to ocean acidification. Front. Mar. Sci. 1:4. http://dx.doi.org/10.3389/fmars.2014.00004.

Gypens, N., Lacroix, G., Lancelot, C., 2007. Causes of variability of the diatoms and Phaeocystis blooms in the Belgian coastal waters between 1989 and 2003: a model study. J. Sea Res. 57 (1), 19-35.

Gypens, N., Borges, A.V., Lancelot, C., 2009. Effect of eutrophication on air-sea $\mathrm{CO}_{2}$ fluxes in the coastal Southern North Sea: a model study of the past 50 years. Glob. Chang. Biol. 15:1040-1056. http://dx.doi.org/10.1111/j.1365-2486.2008.01773.x.

Gypens, N., Borges, A.V., Speeckaert, G., Lancelot, C., 2014. The dimethylsulfide cycle in the eutrophied Southern North Sea: a model study integrating phytoplankton and bacterial processes. PLoS ONE 9, e85862. http://dx.doi.org/10.1371/journal.pone.0085862.

Gypens, N., Lancelot, C., Borges, A.V., 2004. Carbon dynamics and $\mathrm{CO}_{2}$ air-sea exchanges in the eutrophied coastal waters of the Southern Bight of the North Sea: a modelling study. Biogeosciences 1:147-157. http://dx.doi.org/10.5194/bg-1-147-2004.

Harrison, P.J., Hu, M.H., Yang, Y.P., Lu, X., 1990. Phosphate limitation in estuarine and coastal waters of China. J. Exp. Mar. Biol. Ecol. 140, 79-87.

Heisler, J., Glibert, P.M., Burkholder, J.M., et al., 2008. Eutrophication and harmful algal blooms: a scientific consensus. Harmful Algae 8, 3-13.

Hoppe, H.G., 2003. Phosphatase activity in the sea. Hydrobiologia 493, 187-200.

Ivancić, I., Fuks, D., Radić, T., Lyons, D.M., Silović, T., Kraus, R., Precali, R., 2010. Phytoplankton and bacterial alkaline phosphatase activity in the northern Adriatic Sea. Mar. Environ. Res. 69 (2):85-94. http://dx.doi.org/10.1016/j.marenvres.2009.08.004.

Keller, M.D., Bellows, W.K.K., Guillard, R.R., 1989. Dimethylsulfide production in marine phytoplankton. In: Saltzman, E.S., Cooper, W.J. (Eds.), Biogenic Sulfur in the Environment. American Chemical Society, Washington, DC:pp. 167-182 http://dx.doi.org/10 1021/bk-1989-0393.ch011.

Klausmeier, C.A., Litchman, E., Daufresne, T., Levin, S.A., 2008. Phytoplankton stoichiometry. Ecol. Res. 23, 479-485.

Kuenzler, E.J., Perras, J.P., 1965. Phosphatases of marine algae. Biol. Bull. 128, 271-284

Lagus, A., Suomela, J., Weithoff, G., et al., 2004. Species-specific differences in phytoplankton responses to $\mathrm{N}$ and $\mathrm{P}$ enrichments and the N:P ratio in the Archipelago Sea northern Baltic Sea. J. Plankton Res. 26, 779-798.

Labry, C., Delmas, D., Herbland, A., 2005. Phytoplankton and bacterial alkaline phosphatase activities in relation to phosphate and DOP availability within the Gironde plume waters (Bay of Biscay). J. Exp. Mar. Biol. Ecol. 318 (2):213-225. http://dx.doi. org/10.1016/j.jembe.2004.12.017.

Lana, A., Bell, T.G., Simó, R., Vallina, S.M., Ballabrera-Poy, J., Kettle, A.J., et al., 2011. An updated climatology of surface dimethlysulfide concentrations and emission fluxes in the global ocean. Glob. Biogeochem. Cycles 25:1-17. http://dx.doi.org/10.1029/ 2010 GB003850.

Lancelot, C., Spitz, Y., Gypens, N., Ruddick, K., Becquevort, S., et al., 2005. Modelling diatom and Phaeocystis blooms and nutrient cycles in the southern bight of the North Sea: the MIRO model. Mar. Ecol. Prog. Ser. 289, 63-78.

Lancelot, C., Gypens, N., Billen, G., Garnier, J., Roubeix, V., 2007. Testing an integrated river-ocean mathematical tool for linking marine eutrophication to land use: the Phaeocystis dominated Belgian coastal zone (Southern North Sea) over the past 50 years. J. Mar. Syst. 64, 216-228.

Llebot, C., Spitz, Y.H., Solé, J., Estrada, M., 2010. The role of inorganic nutrients and dissolved organic phosphorus in the phytoplankton dynamics of a Mediterranean bay: a modeling study. J. Mar. Syst. 83 (3-4):192-209. http://dx.doi.org/10.1016/j. jmarsys.2010.06.009.

Liu, L., Zhoub, Y., Xiaob, W., Ji, L., Caob, X., Songb, C., 2012. Shifting nutrient-mediated interactions between algae and bacteria in a microcosm: evidence from alkaline phosphatase assay. Microbiol. Res. 167 (2012), 292-298. 
Letscher, R.T., Moore, J.K., 2015. Preferential remineralization of dissolved organic phosphorus and non-Redfield DOM dynamics in the global ocean: impacts on marine productivity, nitrogen fixation, and carbon export. Glob. Biogeochem. Cycles 29, 325-340.

Loebl, M., Colijn, F., van Beusekom, J.E.E., Baretta-Bekker, J.G., Lancelot, C., Philippart, C.J.M., Rousseau, V., Wiltshire, K.H., 2009. Recent patterns in potential phytoplankton limitation along the Northwest European continental coast. J. Sea Res. 61, 34-43.

Løvdal, T., Tanaka, T., Thingstad, T.F., 2007. Algal-bacterial competition for phosphorus from dissolved DNA, ATP, and orthophosphate in a mesocosm experiment. Limnol. Oceanogr. 52, 1407-1419.

Ly, J., Philippart, C., Kromkamp, J., 2014. Phosphorus limitation during a phytoplankton spring bloom in the western Dutch Wadden Sea. J. Sea Res. 88, 109-120.

Mather, R.L., Reynolds, S.E., Wolff, G.A., Williams, R.G., Torres-Valdes, S., Woodward, E.M.S., Landolfi, A., Pan, X., et al., 2008. Phosphorus cycling in the North and South Atlantic Ocean subtropical gyres. Nat. Geosci. 1, 439-443.

Malzahn, A.M., Aberle, N., Clemmesen, C., Boersma, M., 2007. Nutrient limitation of primary producers affects planktivorous fish condition. Limnol. Oceanogr. 52, 2062-2071.

Moran, M.A., Reisch, C.R., Kiene, R.P., Whitman, W.B., 2012. Genomic insights into bacterial DMSP transformations. Annu. Rev. Mar. Sci. 4 (1):523-542. http://dx.doi.org/10. 1146/annurev-marine-120710-100827.

Passy, P., Gypens, N., Billen, G., Garnier, J., Thieu, V., Rousseau, V., et al., 2013. A model reconstruction of riverine nutrient fluxes and eutrophication in the Belgian Coastal Zone since 1984. J. Mar. Syst. 128:106-122. http://dx.doi.org/10.1016/j.jmarsys. 2013.05.005.

Paerl, H.W., 1988. Nuisance phytoplankton blooms in coastal, estuarine, and inland waters. Limnol. Oceanogr. 33, 823-847.

Philippart, C.J.M., Cadée, G.C., van Raaphorst, W., Riegman, R., 2000. Long-term phytoplankton-nutrient interactions in a shallow coastal sea: algal community structure, nutrient budgets, and denitrification potential. Limnol. Oceanogr. 45, 131-144.

Philippart, C.J.M., Beukema, J.J., Cadée, G.C., Dekker, R., Goedhart, P.W., van Iperen, J.M., Leopold, M.F., Herman, P.M.J., 2007. Impacts of nutrient reduction on coastal communities. Ecosystems 10, 96-119.

Pinhassi, J., Gómez-Consarnau, L., Alonso-Sáez, L., Sala, M., Vidal, M., Pedrós-Alió, C., Gasol, J., 2006. Seasonal changes in bacterioplankton nutrient limitation and their effects on bacterial community composition in the NW Mediterranean Sea. Aquat. Microb. Ecol. 44:241-252 (article). http://dx.doi.org/10.3354/ame044241.

Quigg, A., Finkel, Z.V., Irwin, A.J., et al., 2003. The evolutionary inheritance of elemental stoichiometry in marine phytoplankton. Nature 425, 291-294.

Rabalais, N.N., Turner, R.E., Dortch, Q., et al., 2002. Nutrient-enhanced productivity in the northern Gulf of Mexico: past, present and future. Hydrobiologia 475, 39-63.

Rousseau, V., Breton, E., De Wachter, B., Beji, A., Deconinck, M., Huijgh, J., Bolsens, T., Leroy, D., et al., 2004. Identification of Belgian maritime zones affected by eutrophication. Scientific Support Plan for a Sustainable Development Policy-Sustainable Management of the North Sea. Belgian Science Policy Office (Belspo), Brussels.

Soetaert, K., Middelburg, J.J., Heip, C., Meire, P., Van Damme, S., Maris, T., 2006. Long-term change in dissolved inorganic nutrients in the heterotrophic Scheldt estuary (Belgium, the Netherlands). Limnol. Oceanogr. 51, 409-423.

Sunda, W.G., Huntsman, S.A., 1997. Interrelated influence of iron, light and cell size on marine phytoplankton growth. Nature 390, 389-392.

Thingstad, T.F., Zweifel, U.L., Rassoulzadegan, F., 1998. P limitation of heterotrophic bacteria and phytoplankton in the northwest Mediterranean. Limnol. Oceanogr. 43, 88-94.

Trommer, G, Leynaert, A. Klein, C. Naegele, A. Beker, B, 2013. Phytoplankton phosphorus limitation in a North Atlantic coastal ecosystem not predicted by nutrient load. J. Plankton Res. 35 (6), 1207-1219.

van Boekel, W.H.M., Veldhuis, M.J.W., 1990. Regulation of alkaline phosphatase synthesis in Phaeocystis sp. Mar. Ecol. Prog. Ser. 61, 281-289.

Veldhuis, M.J.W., Venekamp, L.A.H., Ietswaart, T., 1987. Availability of phosphorus sources for blooms of Phaeocystis pouchetii (Haptophyceae) in the North Sea: impact of the river Rhine. Neth. J. Sea Res. 21, 219-299.

Zubkov, M.V., Fuchs, B.M., Archer, S.D., Kiene, R.P., Amann, R., et al., 2001. Linking the composition of bacterioplankton to rapid turnover of dissolved dimethylsulfoniopropionate in an algal bloom in the North Sea. Environ. Microbiol. 3, 304-311.

Zubkov, M.V., Fuchs, B.M., Archer, S.D., Kiene, R.P., Amann, R., Burkill, P.H., 2002. Rapid turnover of dissolved DMS and DMSP by defined bacterioplankton communities in the stratified euphotic zone of the North Sea. Deep-Sea Res. II 49, 3017-3038. 